\title{
CASte, Kinship, AND Life-Course: Rethinking Women's Work AND AgenCy IN RURAL SOUTH INDIA
}

Nitya Rao

\begin{abstract}
This paper re-examines the linkages between women's work, agency, and well-being based on a household survey and in-depth interviews conducted in rural Tamil Nadu in 2009 and questions the prioritization of workforce participation as a path to gender equality. It emphasizes the need to unpack the nature of work performed by and available to women and its social valuation, as well as women's agency, particularly its implications for decision making around financial and nonfinancial household resources in contexts of socioeconomic change. The effects of work participation on agency are mediated by factors like age and stage in the life cycle, reproductive success, and social location - especially of caste - from which women enter the work force.
\end{abstract}

KEYWORDS

Women's work, agency, intrahousehold relations, kinship, life course, India

JEL Codes: N15, Z1

RUNNING HEADER: WOMEN'S WORK AND AGENCY IN RURAL SOUTH INDIA

INTRODUCTION 
Debates on the impact of intrahousehold relations on well-being outcomes emphasize the role of women's employment and earnings in enhancing agency, thereby giving them a stronger fallback position, a clearer perception of their own well-being, and a higher valuation of their contribution to the household (Amartya Sen 1990). In India, an association is reported between higher rates of women's labor force participation, greater autonomy, and lower excess mortality, all leading to improved status for women (Tim Dyson and Mick Moore 1983; Jean Dreze and Amartya Sen 1995). Despite the problems of translating "labour into income, income into choice and choice into personal well-being," it is postulated that "making labour markets more accessible to women is likely to have greater transformatory [sic] potential for their position within the family as well as for creating sustainable livelihoods" (Naila Kabeer 1996: 19-20).

This paper questions the primacy given to economic resources, especially engagement in paid work, in shaping women's agency. Instead of labor force participation per se, I analyze the effects of participation, especially in the early years, on women's ability to exercise agency and influence decisions through their life-course. I demonstrate the ways in which decisions in the 'social' realm including fertility, marriage, and education of the children become crucial indicators of agency, mediating the relationship between income, work and well-being. However, these vary, and often in contradictory ways, with women's locations in caste, life cycle, and work and educational hierarchies; they have to be situated within larger contexts of economic opportunities, political mobilization, and social change, emphasising the complex intersections between institutional practices and power relations, ranging from the local to the global (Christine M. Koggel 2003). The conclusions are based on data from five villages of rural Tamil Nadu.

WORK PARTICIPATION AND WOMEN'S AGENCY: EXPLORING THE LINKS 
Defining and valuing women's work has been debated since the 1970s. ${ }^{1}$ Not only are the every day, reproductive tasks allocated to women less recognized than the more visible, productive tasks allocated to men, but activities performed in the public realm get socially recognized and valued, while work within the home is both invisible and limits opportunities for social mobility. This division of activities and their spatial separation are an essential element of the social and symbolic construction of gender, the systematic "non-valorisation of women's labour" which contributes to their subordination (Felicity Edholm, Olivia Harris, and Kate Young 1978: 123). This understanding has led to efforts both to value women's unpaid work and support the expansion of paid work.

Sen (1990) has argued that bargaining models of the household assume that links between interests, contributions, and well-being are clear and unambiguous, but they miss the important role of perceptions regarding what is legitimate, fair, and appropriate. Perception biases become unfavorable to women by distancing their perceived interests from their own well-being, but also inadequately recording their contributions to the household's economic fortunes. He notes that "the perception bias tends to relate to the size of the direct money earning rather than to the amount of time and effort expended" (Sen 1990: 140). While perceptions of visible, gainful work importantly shape intrahousehold bargaining and well-being outcomes, the gendered nature of labor markets, which restrict women's earning potential, alongside gendered expectations of women's household responsibilities become ideological tools for controlling their labor, and constraining them from acting in their own self-interests. Disadvantages in well-being outcomes get transmitted over generations by solidifying men's material advantages in education and employment. 
Second, implicit in Sen's emphasis on the linkages between women's work outside the home and their agency is the continued undervaluation of women's reproductive contributions. My field data demonstrates that this is not necessarily the case - reproductive success in terms of producing children, especially sons, and their 'quality' upbringing and nurture are highly regarded in the local context. Children are seen as both a resource and a strategy for upward mobility, especially in engaging with the 'modern,' nonfarm sector and expanding social networks outside the community, caste, and kin group. Reproductive activities are hence valued, though their content changes over both time and the life-course. Understanding this shift in valuing women's reproductive work within the particular social context becomes crucial for gauging women's agency at a time when rural women's work participation in India appears to be not just stagnant, but declining (National Sample Survey Office [NSSO] 2010: 65). ${ }^{2}$ Even among working women, over 50 percent are self-employed, with close to three-fourths of them engaged as unpaid household labor, especially in rural areas (Indrani Mazumdar and Neetha N. 2011).

In the case of India, gender identity is conditioned by longer-term associations between caste identity and economic status. Women's entry into paid employment is often necessitated by the overall deprivation and marginalization of the lower castes and classes, especially the Dalits $(\mathrm{SCs})^{3}$, and is hence also an indicator of low social status rather than of (women's) personal worth or empowerment (Joanna Liddle and Rama Joshi 1986). We need therefore to think very differently about both paid work and domestic labor (including reproductive labor) in contexts where social inequalities and their signifiers cut across gender identities.

Naila Kabeer (1999) emphasizes that the process of empowerment is incomplete without an exercise of agency while still acknowledging the importance of both access to resources (including employment) and final well-being outcomes in contributing to this process. In fact, a 
sense of agency - including dimensions such as freedom of movement, access to resources, and decision-making capacity - are seen as key characteristics of persons as "fully operative individuals" (Laila Garda, Mallika Alexander, Rajib Acharya, Savita Kanade, and Shireen J. Jejeebhoy 2010). Just as the experience of work is complex, so is agency; neither can be unravelled without taking into account other key elements of women's or men's identities: in particular, caste, social differences, marital status, stages in the life cycle, kinship support and individual attributes, as well as contextual changes over time. The relational dimension of women's agency and its multiple and often conflicting meanings become as important as individual goals (Isabelle Guerin, Santhosh Kumar, and Isabelle Agier 2013).

Rather than Sen's (1990) emphasis on employment and education, women's bargaining power in such contexts can be better explained by their access to social support systems (caste and kinship networks) as well as institutional support from the state and nongovernmental organizations, what Marjorie B. McElroy (1992) describes as Extra-Household Environmental Parameters (EEP). Dravidian kinship systems, practiced in Tamil Nadu among both Dalits and other castes, are different and more flexible than the classic patriarchy of northern and western India, with cross-kin marriage and a corresponding emphasis on affinal relationships being the preferred social norm (Karin Kapadia 1995; Kathleen Gough 1981). This is confirmed by the survey data which found 58 percent of Dalits and 35 percent of the Other Backward Castes (OBC) married to their own kin. Young wives are familiar with their in-laws prior to marriage, and instead of natal rupture, support from the natal family is both expected and given, enhancing their agency in the marital home.

At the same time, the state's social welfare provisioning - supplying cheap food grains through the Public Distribution System (PDS), ${ }^{4}$ child nutrition through the noon meal scheme, 
universalization of basic education (K. Seeta Prabhu 2001), the implementation of guaranteed work for a minimum of 100 days per household (as part of the Mahatma Gandhi National Rural Employment Guarantee Programme), and more recently, substantive maternity benefits have contributed to shaping women's agency in transformative ways, ${ }^{5}$ typically through opening up the choice of whether to work. This choice is often unquestioned in neoliberal paradigms, but it has rarely existed for rural, low caste, working-class women forced to enter low-paid work, often in near-bonded conditions, both for survival (S. Charusheela 2003) and to enable their husbands to seek more remunerative, off-farm work (Lucia da Corta and Davulari Venkateshwarlu 1999). Gender here becomes constitutive of labor market segmentation and social inequality more broadly.

Women struggle to gain recognition for their productive and reproductive contributions to the household and use this recognition to exercise greater control over their life and body (labor). Clearly, work participation can have different outcomes in terms of well-being. Paid work can enhance monetary contributions and lead to a sense of self-worth; it can also increase women's drudgery and work burdens. Poorly remunerated work further devalues their labor time without enhancing agency - it can be oppressive and exploitative rather than empowering (Judith Heyer 2014). This raises an important question about the nature of work itself and the terms of participation, which may often, rather than recognizing women's contributions, reinforce representations of men as household providers.

Economic evaluations, important for gaining visibility for women's work and securing entitlements, sometimes forget important elements shaping women's engagement in the work process. Crucial here are the issues of identity, positionality, and respect, created and recreated through involvement with and control over wider processes of social reproduction. Embedded as 
they are in power dynamics within social and economic interactions between unequally structured relationships, current conceptualizations of social justice and the economic domain do not give them adequate weight. Unless the inter-linkages between work, recognition, and agency are problematized and unpacked, it is difficult to understand changes in women's status or empowerment and how they shift through the life-course.

\section{CONTEXT AND METHODOLOGY}

This study is located in a five-village cluster on the border of Coimbatore and Tiruppur districts. The Tiruppur industrial cluster, a global center for the production of hosiery and garments, offers diverse employment opportunities to local workers. Technically such work is open to all castes and both genders, but Dalits remain excluded from the better-paying jobs, largely occupied by the Gounder caste, and are confined to laborious tasks (Sharad Chari 2004). A disproportionate number of Dalits still remain dependent on agrarian livelihoods (Judith Heyer 2010).

Social bonds and power relations are crucial in the context of agrarian labour in rural Tamil Nadu. Gunnel Cederlof (1997), in tracing the interdependent but hierarchical relationship between the landowning Gounders and the landless Madharis (Dalits) between 1900-70 points to the interlinkages between the economic contract and social duties (urimai) on both sides. Permanent labor (pannaiyal), seen as a form of bondage resulting from indebtedness in the early twentieth century, became a privilege by the 1960s, representing as it did regular work, wages, and additional rights to their master's patronage in times of drought and insecure employment. It had almost disappeared by the early twenty-first century, having already transformed from a permanent, life-long relationship to a form of temporary attachment based on both cash advances and daily cash wages (Geert De Neve and Grace Carswell 2011). Heyer (2010) attributes this change in labor relations since the 1980 s to both the reduced need for year-round labor by 
employers due to shifts in cropping patterns and the growing unwillingness of Dalits, especially the educated, to work for low wages under tied labor conditions. The growth of the industrial economy and improved transport and communication has also contributed to this process.

Other village studies in Tamil Nadu also point toward the following changes over the last twenty-five years: diversification of the rural economy, expanding opportunities for rural men in the nonfarm sector, Dalit political mobilization, and state-welfare provision (J. Jeyaranjan, John Harriss, and K. Nagaraj 2010; Göran Djurfeldt, Venkatesh B. Arthreya, N. Jayakumar, Staffan Lindberg, A. Rajagopal, and R. Vidyasagar 2008). Tamil Nadu has a long history of political mobilization and social reform. Periyar's "Self Respect Movement" in the early twentieth century focused on the emancipation of the lower castes (adi dravidas) and women (V. Geetha and S.V. Rajadurai 1998). While personality politics in the Dravidian parties led to a dilution of this ideology since the 1960s, Dalit mobilization and assertion for equal rights and the implementation of constitutional guarantees, though largely patriarchal and male, has increased (Hugo Gorringe 2005). Partly in response to this mobilization and partly in constructing itself as a "welfare state", Tamil Nadu has seen consistently high social sector expenditures and several schemes for women and children (K. Seeta Prabhu 2001). Together, these have contributed to a decline in the hegemonic control by large farmers over village life.

Irrespective of the degree of social transformation, these macro shifts have implications for micro-processes, particularly the sexual division of labor in the household; understanding them provides insights into relative bargaining power and the ways in which women negotiate their claims in the household. With a few exceptions (for example: Heyer 2014), what these studies generally miss is the transformation in gender relations amongst the Dalits, albeit silent, with Dalit 
women for the first time having a choice on whether or not to work, at least during their reproductive years.

This paper combines data from a household survey of 400 rural couples, in-depth interviews with forty of the couples, and key informant interviews with six community leaders. Men and women, currently living together in conjugal relationships, were interviewed separately, both in the survey and in-depth interviews, to gauge their perceptions about their own and their spouse's contributions to the household, experiences of work, and final say in household decisions. The data were collected between February and December 2009. Ideally, long-term engagement is essential to comprehend the changing contours of the interaction between the life and work processes of women, as the exercise of agency varies with their subject position at a particular point in time, as well as changes in the socioeconomic contexts in which they live (Nitya Rao 2008). I sought to overcome this limitation through open-ended discussions during the qualitative interviews, but also by situating these narratives in the literature on change in economic and social relations in this location, ${ }^{6}$ and Tamil Nadu more generally, for insights into the linkages and hierarchies between the social-symbolic and the material domains in people's lives.

Thirty-five percent of the sample comprised Dalits, mostly Madharis, the lowest status Dalit group in the region, while 58 percent were OBCs. The latter included two distinct groups the landowning Gounders and the handloom-weaving Devanga Chettiars (DC) - differing in terms of landowning status, social norms, networks, lifestyles, and gender relations. Seven percent belonged to other caste groups. While the qualitative interviews are disaggregated by these subgroups, the survey only recorded the aggregate categories of SCs and OBCs.

\section{INSIGHTS FROM THE FIELD}


Alongside the mass literacy campaigns, Tamil Nadu initiated measures to expand the reach of primary education in the early 1990s. Few of the younger Dalit women interviewed, however, got through primary school. In the study sample, 63 percent of Dalit women below the age 30 remain barely literate in contrast to 17 percent of the OBCs (Table available on request). Such large variations in school completion rates by social group and gender are in line with figures for the rest of the country (Sonalde Desai and Veena Kulkarni 2008). The children of Thulasi, a 35-yearold Dalit woman, became coolies (casual agricultural labourers) instead of attending middle school since they were harassed by other children and teachers. She tried complaining, but in vain. The way in which Dalit children are treated at school is just one indicator of the larger social milieu marked by hierarchical, caste-based relations that perpetuate and reproduce a host of other deprivations including indebtedness, discrimination, and sometimes abuse (Grace Carswell and Geert De Neve 2014). They also live in separate parts of the village.

Our survey found extreme disparity in land distribution: 94 percent of all households were landless, 98 percent amongst the Dalits and 90 percent amongst OBCs. Land is largely controlled by the Gounders (OBC), an agricultural caste. In-depth interviews with key informants confirmed a process of agriculture giving way to the textile and hosiery industry, power-looms, and construction - particularly since the 1990s. In agriculture, food crop farms have given way to coconut plantations and poultry farms. Reasons for this include declining water tables resulting from the over-exploitation of groundwater following electrification in the 1950s and 60s and the unavailability of cheap labor. The rapid development of wind energy in the locality has further made the land underneath the windmills uncultivable.

Table 1 depicts the main work activities identified by men and women of different castes in the survey. Most Madharis, men and women, are casual wageworkers, and a small proportion 
work as annually paid farm servants (pannaiyals). Women, earlier employed in the cultivation of maize, cholam (sorghum), ragi (millets), onion, chilly, tobacco, and cotton, now work in poultry farms and occasionally plantations. Their wages however are unequal, with the survey finding women earning around half that of men for similar work. The NSSO $64^{\text {th }}$ Round Report notes that, for Tamil Nadu, women's average wage for regular work is Rs $87^{7}$ per day and casual work Rs 51 per day in 2007-8 as against Rs 158 and Rs 100 for men (NSSO 2010). Though the survey did not disaggregate the data by subcaste, field observation and interviews revealed a marked difference within the $\mathrm{OBC}$ category. The Gounders work on their own farms or as casual workers in factories, power looms, or other enterprises, while the DCs are self-employed in weaving. Educational levels don't change this pattern of work, pointing to the difficulties, especially for the Dalits and women, of breaking free from casual agricultural labor and other traditional occupations into new employment opportunities (Barbara Harriss-White and S. Janakarajan 2004).

(Insert Table 1 here)

Analysis of activity patterns by age shows that men across castes report becoming "not active" after age 60 . There is a life-cycle pattern, with all men starting with casual work. For the Madharis, this casual work persists through their lives, causing frustration as they age and finding work gets increasingly difficult. The Gounders eventually settle down on their own farms or set up enterprises like power looms and poultry farms, and DCs return to work on their looms (after age 30). For the Gounders and DCs, the early years are of experimentation, but their resource base, whether land or weaving skills, gives them a niche to develop their future careers. 
For women, these life cycle shifts are starker. They bear and rear children in the early years of marriage and thereafter enter the workforce to withdraw after age 50. Two points deserve special attention. First, the participation and contribution of Dalit women to household incomes is well established (Kapadia 1995; Joan P. Mencher 1988), but this seems to be changing. The survey found nearly 25 percent of women reporting themselves as not active in the workforce or engaged only in domestic work. Second, work participation of OBC women is fairly high, only 35 percent reporting being not active or engaged only in domestic work. This can be understood only when further disaggregated by caste and age. The DC women, in the 30-50 age group, were all involved with home-based weaving alongside childcare and other domestic duties. Only the Gounders, including the higher educated, could afford to be full-time homemakers for a considerably longer period of time, perhaps throughout their married lives. The importance of life cycle in shaping the pattern of women's employment, as indeed men's employment, and its interaction with social/caste identity has to be emphasised.

Apart from agricultural and construction labor, some Dalit women work in cotton spinning mills, but the terms are not easy. As Dhanalakshmi, 33, said, "I was a construction worker, but this was taxing on the body, so I joined a spinning mill. I wanted to work one shift, but they made it compulsory to work two. I don't have time for anything else now." While capitalism, including global capitalism, does provide opportunities for work, this does not necessarily enhance women's choices (Koggel 2003: 168). The mills, by not recognizing women's domestic and care work, limit the options for most of them to casual, manual labor and piece-rated work, carding thread or packing finished garments.

Forty-year-old Thirumal worked as an agricultural laborer. Following the birth of her children, she experienced poor health, and found manual labor difficult. She said: 
I card thread from the waste cloth given by the factories. They pay Rs 10 for carding a kilo of cloth. Working continuously from morning till night I manage 3-4 kg. My shoulders ache at night. My husband, however, earns Rs 100 per day. Carding waste cloth fetches Rs 30-40 a day, agriculture and construction work between Rs 60-80 per day, all lower than the minimum wage of Rs 100 for agricultural workers in Tamil Nadu. The hard working conditions make many Madhari women leave the workforce at particular stages in their life cycle, typically when their children are young. When employment is exploitative and unrewarding, withdrawing from work is not just a relief from hard physical labor, but also a reflection of women's agency. Women like Dhanalakshmi and Thirumal do not engage with paid work out of choice or to enhance bargaining power at home; rather their work participation reflects the limits to their power in both the productive and reproductive spheres. The ability to not work, even temporarily, enabled by state provision of subsidised food grains and the generally tight labor market, supporting higher male earnings, remains an aspiration for many.

The Gounder women, especially older ones, work on their own farms, and also secure and supervise Dalit labor when needed. Younger women like Sakuntala, discussed later, albeit educated, focus on homemaking, or, like Eswari's daughter-in-law, seek regular, salaried work in or around the village. They have by and large retained their dominant social status, and their activities are guided by the demands of social prestige rather than material need.

The DC women all support their husbands on the loom. However, rather than earning income independently, they remain "unpaid household helpers." Nesmani and Mallika echoed each other in saying, "My husband doesn't want me to work outside but help him on the loom." The saris produced are sold either to private traders or to the handloom cooperative; both marketing channels in men's domain. The men acknowledge the critical role of their wives, who 
prepare the thread and sometimes weave, yet as noted by Maria Mies (1982) in the case of the home-based, lace-makers of Narsapur, caste and gender norms contribute to labelling women's productive work as 'leisure' or 'house-work,' giving them no control over either the conditions of work or its proceeds.

Withdrawal of women from the workforce has been viewed as a symbol of status and upward mobility in India. Not just amongst the OBCs, but amongst the Dalits too, a strong discourse exists of homemaking and childcare as essential components of women's identities. The survey found a gap of less than 10 percentage points between Dalit and OBC women reporting their primary activity as domestic work. I explore next whether this necessarily means a loss of autonomy and increasing subordination for Dalit women by examining the nature, content, and valuation of women's work among these different groups and its implications for women's agency through their life-course. In particular, I point to the intersections between the social domain and their economic lives.

\section{WOMEN'S AGENCY THROUGH THE LIFE COURSE: ANALYSING QUALITATIVE DATA} Heyer (2014), in a long-term study of two villages in Tamil Nadu's Coimbatore district (1981-82, 1996, and 2008-09), found the proportion of women reporting themselves as housewives increased from 22 percent for Dalits and 29 percent for non-Dalits in 1996 to 35 and 53 percent respectively in 2008-09. Such reduction in workforce participation has generally been associated with a decline in Dalit women's status within their own homes (Ashwini Deshpande 2007), but Heyer (2014) notes that this might equally be seen as benefiting women in a community emerging

from extreme poverty. Women's withdrawal from the workforce is linked here to the enrolment of virtually all the children in school and is supported by expanded state social policies and higher 
earnings by men, in contexts where the women themselves are unable to get the kind of employment that would strengthen their position within the household.

I draw here on the qualitative data to examine whether withdrawal from the workforce is by choice for Dalit and other women in the area and examine implications for their bargaining power and agency caused by this withdrawal. Of the forty couples interviewed, seventeen were Madharis, nine DCs, eleven Gounders, and three of other castes. The quotes presented in this section are reasonably representative of the particular age and caste category to which they belong, and were chosen for their clarity of articulation on particular issues.

As noted in the previous section, Madhari women have limited access to the expanding employment opportunities in Tiruppur; the hard terms of factory jobs render homemaking difficult. Several of them were quite explicit in stating that their husbands insisted they stayed home to cook and look after the children. Mylaal, 22, said:

I wanted to go for mill or roadwork, but my husband told me not to take a job as he could earn enough. He insists I'm home when he returns from work. He has never beaten me, nor got angry, and has complete faith in my decisions.

Not engaging with paid work presently has not reduced Mylaal's mobility or voice in household decisions. In her social environment, gaining recognition involves maintaining an image as a good woman, wife, and mother. Her conforming to these social pressures has led to an increase in both personal independence and agency. This needs to be located not just within the changing structure of the economy, but also within the changes in the household domain. Mylaal is an unschooled daughter of agricultural labourers. Food scarcity at home led to her coming to Tiruppur at age 14 to work in a banian (hosiery) factory. Her father remarried, so she returned to support her mother, accompanying her for farm work. She said: 
I was barely 16 then. Someone in my husband's family impressed with my taking on so much responsibility came with a proposal for marriage. I refused at first. In a few months they returned and I agreed. I started working in a mill. Initially I got on well with my in-laws, but soonmy mother-in-law started squabbling with me. I was pregnant, but after our daughter was born, we set up a separate household. I gave up the mill job to look after my child. Now I have a son too.

Mylaal had a good reputation as a sincere, hard, and responsible worker prior to marriage. Her husband, who works on a power loom, follows her advice on major investments and family decisions, including setting up a separate household, despite being the only son of his parents. He noted:

I am lucky to get such a good-natured wife. She is frugal, ensures timely food and looks after the children well. I asked her to stay at home and not go for work. I hand over all the money to her, and have full confidence in her decisions.

There was a second element in Mylaal's agency, and this was her reproductive success. She opined:

We get affection and support if we have children. It doesn't matter then if the parents in law squabble with us. But childlessness is a matter for concern. Having children, at least two, is good, as others won't speak ill of us.

Just as men face social pressures to earn and provide, women face pressures to reproduce, in particular to produce sons. If they are successful, this in itself gives them considerable voice in the conjugal relationship.

Early experience of work and reproductive success apart, a third element contributing to Mylaal's agency is the favorable policy context in Tamil Nadu. The availability of cheap rice 
through the PDS, and maternity entitlements, has created an enabling environment in which women like her are not forced to engage in paid work for survival. In Mylaal's words, "My daughter was born by caesarean section in the government hospital. I got Rs 3000 from the state after her birth. We also get rice cheaply from the ration shop, so can manage somehow." Despite a recent decline in social sector expenditures from 2005-8 (Government of Tamil Nadu [GoTN] 2009), especially to education, public health, and rural development, Tamil Nadu has maintained its allocation to nutrition and social services (Judith Heyer 2012).

Women like Mylaal, whose husbands have regular jobs, have been saved from work involving intense drudgery. Others like Thirumal, with four daughters, and a husband making increasingly irregular contributions, have been compelled to take up low-paid informal work, to retain some element of both self-respect and voice, apart from daily survival. She narrated: I suffered a lot the last five years. My husband goes to Kerala for work and comes home twice a month. He would give 2-3000 Rupees every month for food and household expenses. I don't know why he changed. Someone must have cast a spell. Now he beats me, and in the last six months hasn't given any money for the household. This followed the elopement of our second daughter. My husband got furious and thrashed me for neglecting her. I lodged a police complaint. My third daughter, only 14, now works in a mill. She stays in the compound, is paid Rs 1000 monthly and will get a lump sum of Rs 50,000 at the end of her three-year contract.

Thirumal makes several important points in her narrative. She has always worked, but her ill health makes manual labor difficult, and she is unable to earn enough. She points to the love and affection she got from her husband in the past; he even helped sometimes with the cooking and washing. She has not produced a son, nor has she been successful in educating her children. 
Perhaps the final blow was the elopement of her second daughter. It seemed to reflect her inability to manage her home and children well, and evoked a violent backlash. Yet, she has fought back, her strategies for exercising agency changing as her life has progressed and the resources available to her changed. Her daughters have been a source of strength, rather than a burden as is often assumed, helping earn money to run the household. Strong bonds and mutual support exist between mothers and daughters and constitute a central element of women's agency, made possible by the acceptability of village endogamy and close-kin matrilateral marriage.

As Thirumal's daughters married and left home, she started using external resources such as the police to protect her from her husband's violence. She blames liquor and bad influence for the change in his behavior, yet married for over twenty years, she does not see divorce as an option. Her husband, aged 45, is a coconut plantation worker. He described their 'love' marriage, knew accurately about her carding waste cloth, and spoke as if nothing had changed between them. He mentioned giving her money for household expenses and consulting her on all matters. He did not divulge the recently deteriorated relationship, the violence, or the police complaint. His silence was perhaps linked to notions of self-respect as well as his attempts to conceal his inability to provide adequately for his family or indeed control his wife's actions - key elements of his masculine identity. Thirumal's voicing her experience on the other hand was an expression of her agency and attempt to transform the meanings of their relationship to those of mutual care and responsibility, as expressed in her desire to see him become his old self.

None of these Madhari women, young or old, are educated, and all started paid work early, around 14 years. In a context of poverty, children, particularly girls, bear a burden of financial responsibility alongside supporting their mothers socially and emotionally, contributing to the persistent gender gaps in education, despite the state policy of universalization. The experience of 
work and earning, however, gives them a say in decision making in their parental homes, a degree of marital choice and recognition from their husbands.

Apart from the experience of work in the early years, caste is an important factor influencing agency. Inherent in caste are differences in the norms of appropriate behavior and conduct for women. For most Madharis, participation in paid work remains an important part of their lives and roles; this also seems to be the expectation for DC women. Landless weavers, skilled on the loom, and better off than the Madharis, the DC women are still poor. Their norms, assets, and work patterns differ greatly from the Gounders, the landowners and entrepreneurs. Both are classified as OBCs, but the latter operationalize rigid gender norms regarding women's work. For them, the nuances of agency derive from very different factors compared to the Madharis, though as Table 2 reveals, women's role in decision making among these groups, at least their representation of it, seems restricted. The practices vary as the narratives reveal, with most young Gounder women now attaining higher education, then either taking a job or moving to the city after marriage, but the norms continue to reflect the status quo.

Mallika, age 29, a DC, has a 6 year old son and a daughter who is 3. Leaving studies at age ten due to poverty, she worked on a power loom for Rs 70 daily. After marriage, her husband, educated till grade six, wanted to start a business. They sold her jewellery for Rs 30,000 and invested the money in a contract for securing banian waste from the factories, getting it cleaned and selling it to workshops. Mallika said,

With good cloth we earn Rs 500 per day. Unfortunately the business has not been successful. My husband loafs around engaging in politics. I wanted to work in a mill, but he wouldn't allow me. I help him on the loom. We make three saris a week, and get Rs 400 per sari. He gives me Rs 300 weekly for household expenses 
and additional money if I need it, but takes all the decisions. He is confident and has a lot of contacts. Every marriage has its ups and downs and we have to sail along. I worry about our financial condition. We don't have a house or any savings.

Her husband too spoke of their precarious finances. His parents died when he was young, and he took large loans for his own and his sister's wedding. They moved to Tiruppur for four years where he worked as a cutting master but returned to the village once their first child was born. He said that his wife was very outspoken, telling him not to waste time drinking with his buddies. Sometimes he hit her in anger but would soon make peace. He was now trying to become a sari retailer to earn some extra money. He did the household purchases and made all major decisions, but his wife decided that their son be admitted to an English-medium school.

Despite Mallika's premarital work experience and articulateness, unlike the Madharis, her husband continues to control the finances. Her jewellery has been sold, but she has rarely been consulted on major investment decisions. Yet her husband recognizes and values Mallika's work at home and on the loom. When she is upset he placates her by apologizing first. Though he makes the business decisions, in matters of the children's health and education, she has the final word. This suggests that the nature of decision making within the household is divergent, with women responsible for the education and health of children, and hence charged with decision making on these counts, irrespective of whether they earn income or not. This is in line with Shelley Lundberg and Robert A. Pollak's (1993) view of household decision making that sees women and men responsible for separate spheres of activity and decision making in these spheres. Women like Mallika engage in production as unpaid household helpers; their voice in household matters is not directly linked to their work participation or economic contributions, but in domains that are seen to lie in their area of experience and expertise. 
This hypothesis gains weight in the context of a counter-example. Childlessness gives Vasantha, age 36, little say in household decision making, even though she weaves saris along with her husband. Married at age 18, she conceived twice, but miscarried both times. She has been unable to conceive again.

I did the housework. But my mother-in-law would taunt me saying, 'If you had a child you would know the value of the family.' I sold my jewellery for hospital expenses. After the second miscarriage, I went to the hospital every month for three months. When the money ran out I had to discontinue the treatment. I want to adopt a child, but my husband disagrees.

Her husband affirmed making all decisions and doing the shopping and said he gave her Rs 100 a week for her own expenses. As a self-help group member, she deposited Rs 25 weekly. He rued "I am still very fond of her, only feel sad that we don't have a child. I have not yet taken a decision regarding adoption." Vasantha finds her sphere of influence quite restricted, even though in everyday terms, she and her husband share all tasks. Decisions regarding work and investment are largely taken by her husband. She exercised agency by seeking treatment for infertility, but lack of resources meant this could not be completed. She has been pushing for adoption of a child as a way of securing her own position, as childlessness is a common cause for desertion, a point implicitly raised by Mylaal. Engaging in productive work does little to promote women's agency in this context, especially as it is conducted within the home and the income appropriated by men (Marilyn Carr, Martha Alter Chen, and Jane Tate 2000). Rather, it is reproductive success that appears critical.

For Gounder women, the life-course position makes a big difference to both status and voice. Eswari, 65, was married at 15 to her mother's brother. Her husband had eight acres of land 
and she got two acres and twenty sovereigns (160 grams) of gold in marriage. After a year she had her first son and then two more boys. She assisted with farm work. They were not wealthy; their land was un-irrigated, so she sold her jewellery to pay for her sons' education. All three are now employed; the youngest son and daughter-in-law live with her. The son works in a factory. His wife prepares the local school mid-day meal and does the house work, while Eswari looks after her grandson. Her husband is old and cannot do much, so she manages all household expenses. Amongst the Gounders, women are more restricted, but as they grow older and gain status, especially as the mother of a son, they wield considerable power.

Younger women seek to exercise influence covertly. Sakuntala, 26, completed secondary education, and worked for three years in a gold ornaments factory before marrying at 19 . She now has a son and a daughter. Her husband, a trained electrician and mechanic, runs a cable television business. She has often offered to work to repay their home loan, but her husband insists she stay at home caring for the children and doing the household chores. It was his responsibility to earn for all of them. He earns well, manages the household budget, does the purchases, yet gives her views serious attention. She was influential in their purchasing an expensive house that necessitated selling three acres of land and seeking a loan. Despite not earning, Sakuntala is considered a good wife and caring mother by her husband, so her opinions count in household matters. The value of reproduction is crucial to her status. Education perhaps plays a role, though it is hard to establish a clear correlation.

The above narratives show the variations in factors influencing women's voice in the household - from work participation early in life amongst most Madharis, to the birth of sons and the performance of reproductive roles amongst the Gounders and DCs.

\section{QUANTITATIVE INSIGHTS: GENDERED DIMENSIONS OF DECISION-MAKING}


While noting the difficulties of generalization and the potential biases in responses to questions on decision making, an index was nevertheless constructed to shed light on the variations in perceptions about women's involvement in decision making across the different domains of everyday life - the productive, reproductive, and personal (Tables 2 and 3). The productive domain, captured by the financial provision index, is derived from five questions (decisions on purchase of major goods, wife working outside the home, purchase or sale of jewellery, expenditure patterns, and borrowings); the reproductive domain includes the children's upbringing index, derived from two questions (addressing child illness and schooling provision); and an index on running the household, based on two questions relating to the preparation of food and inviting guests home. The personal domain is represented by the fertility and marriage index, which is again based on two questions that deal with decisions on the number of children to have and whom to marry. Using age/generation (Table 2) and education (Table 3) as the principle variables, the data is disaggregated by caste and women's self-reported work status, given the importance in the literature to the relationship between women's paid work and agency. It is important to clarify that the codes 'working' and 'not working' refer to 'productive' or 'paid work' or not. An index of 1 reflects perfect equality in men's and women's perceptions of agency, less than one reflects male dominance, and greater than one female dominance.

Significant in both tables is the distinct difference in women's involvement in decisions on financial provisioning versus social reproduction, namely running the household and bringing up the children. All women, whether SC or OBC, working or not working, have a greater say in decisions around running the household and bringing up children, in fact for nonworking women this appears at par with or sometimes even stronger than for working women. There are differences according to caste and age (used as a proxy both for the stage in life-cycle and 
generation). The role of education is unclear, depending on the level attained. I discuss some of these differences below.

(Insert Table 2 and 3 here)

The most obvious point that emerges from the tables is that Dalit women have more agency than OBCs almost across the board. In the domain of financial provisioning, work status remains important (except in the oldest age group), with Dalit women losing some advantage when they stop working. It is somewhat surprising that even in the upbringing of children, which carries a premium in this region across caste groups, Dalit women exercise greater agency than OBC women. This could perhaps be explained by Dalit women's direct contributions through work and earnings, especially when their children are in the school-going age.

Crucial from the point of personal empowerment is women's ability to control their own bodies and lives, reflected in strategic decisions around fertility and marriage. This is an area that really points to persistent caste differences and the advantage that Dalit women hold. In the youngest age group, both working and nonworking, Madhari women have control over their fertility and choice of marriage partner. Current work status hardly plays a role; elder women also appear not to have a prominent role in such decisions, pointing to a continued prevalence of selfarranged marriages amongst the Dalits (Kapadia 1995; Nitya Rao 2012).

In terms of age or generation, while women do gain status and power as they become mothers, especially of sons, and mothers-in-law, especially in relation to financial matters, younger women appear to have greater agency in the reproductive domains. One possible interpretation of the household management and child upbringing indices is that as older women 
no longer have young children, they don't exercise agency in matters of child schooling and health. But it could also imply that younger women have much greater voice than the older women ever had in these domains, for instance, which school to send their child to - private or state, whether to engage private tutors, or move to a town to access better healthcare and education. The fieldwork did suggest that current choices are much more complex, and younger women are involved in a plethora of inter-related decisions.

The role of education is, however, ambiguous. Secondary education appears to improve Dalit women's choices both in terms of employment options and their personal lives, but with a limited sample of only two such women it is difficult to make a definitive statement. No such trend is seen amongst the OBCs, where men's influence persists in both the productive and personal domains. Older OBC women seem to have some advantage over younger women; mothers-in-law influence decisions about their daughter-in-laws' fertility and mothers over the marriage of their children. Education of the younger women does not seem to count for much.

Before concluding, it is worth pointing to the contradictory tendencies that emerge from the data, most strikingly in relation to the personal and productive domains. Younger women, especially Dalits, with more education and more economic power are able to override some of the constraints they face to maintain strategic control over their key life decisions. Among the OBCs, the data seems to suggest a trade-off between education and the age-caste nexus, with less educated, older women, dominating over often more educated, younger women. What emerges is a complex picture of women's agency, decision making and status, varying with specific intersections of caste, age, education, and work status.

\section{CONCLUSION}


Women's paid work outside the home has generally been associated with enhanced agency and empowerment of women. Based on a 2009 field study in India, this research finds reproductive work emerging as a central factor shaping women's agency across caste groups.

In principle, women can find employment in the hosiery and spinning mills in Tiruppur, but as in other manufacturing for global production, young, unmarried women, who can work several shifts, are more able to engage with such schedules than married women with childcare and domestic responsibilities. In the absence of resources, social networks, and support systems, it has not been easy for women in general and Madharis in particular to penetrate the hosiery sector, and if at all, this has involved hard and inflexible working conditions. The alternative is low-paid, piece-rated work, and, for the majority, agricultural labour. Productive work was discussed extensively by Madhari women, but more as a burden than source of agency.

It is clear that women's say is not linked to their work participation or economic contributions alone. The fact that there is less suitable work available to women in the locality has not necessarily meant a reduced status in the household. This is mediated by factors such as the stage in their life-course, the mutual support between mothers and daughters, their work experience early in life, reproductive success, especially the birth of a son, supportive state policy, and most importantly locally constructed gender ideologies, especially those linked to caste identities and statuses. The valuation of domestic work and the successful upbringing of children, perceived as an important contribution to the social reproduction of the household and its future security, is relatively high, in fact, more so than the incomes women bring. This shift in the social valuation of women's work is both specific to the local context and relatively recent.

Women's voice then appears greatest in areas that are seen to reflect their roles, such as childcare, rather than in matters of production. Decision making seems to be differentiated into 
two distinct spheres - production and reproduction - irrespective of participation or contributions; these are seen as the primary responsibility of men and women respectively. Understanding women's agency therefore requires a disaggregation of domains of decision making and the nature and processes by which decisions are made. Given the deep interconnections between them, in practice, women are able to negotiate some authority in matters broadly affecting household livelihoods. Alongside workforce participation, the importance of education (and nuclear households) has been emphasized in shaping decision making, particularly in South India (Shireen J. Jejeebhoy 2000). The role of education per se is not clear-cut; the level and quality matter.

The social preference for women as housewives, focusing on the reproductive realm, and men as providers, enables them to withdraw from the workforce at specific points in their life cycle, such as when the children are young, their husbands are able to earn a regular income, or when appropriate employment is unavailable to them. Such decisions are supported by improvements in state infrastructure, services and welfare schemes. However, caste differences persist. For the DCs, engaged in home-based work as unpaid household helpers, this option does not exist, as for the poorer Gounders. For the better off Gounders, the option has always existed work has been a choice rather than compulsion. It is only amongst the Madharis (Dalits) that ideological shifts in social expectations combined with state provision have effectively expanded their choice of whether or not to engage with paid work, especially if harsh and degrading, enhancing women's bargaining power vis-à-vis their potential employers and their husbands. For such transformative outcomes to be sustained, notions of equality need to be built into conceptions of social protection and its provision. Rather than being seen as welfare services supporting 'vulnerable' women, they need to reflect recognition of women's contributions to social reproduction as valuable and hence legitimate claims as equal citizens. 
This relationship between women's work and agency varies with context. Unless the local idioms and meanings of work, differentiated in the Indian context by caste, age, stage in the life cycle, and education, are understood in their contextual settings, appropriate policy interventions cannot be made. Work participation has to be examined according to the type and conditions of work available to women, with withdrawal from the active workforce often being preferable in a context where there are few decent work opportunities available. This however raises questions around the recognition of women's contributions and ensuring their voices are heard in the making of key strategic household decisions. For researchers, the challenge is to develop contextualised indicators for understanding women's agency.

Nitya Rao

University of East Anglia - School of International Development

Norwich NR4 7TJ

United Kingdom

e-mail: N.Rao@uea.ac.uk

\section{BIOGRAPHY}

Nitya Rao is Professor of Gender and Development at the University of East Anglia. She has worked extensively in the field of women's organization, employment, and education for close to three decades. Her current research interests include gendered changes in land and agrarian relations, food and nutrition security, migration and well-being, intrahousehold relations, equity in education programs and policies, and the gendered nature of economic growth. Her research has mainly been conducted in South Asia. 


\section{ACKNOWLEDGMENTS}

I thank the DFID-ESRC research funding for the project RES-167-25-0251 - The intra-household allocation of resources: cross-cultural tests, methodological innovations, and policy implications, for making this field work possible. I am grateful to Amit Mitra, Mina Swaminathan, participants at the BASAS Annual Conference, 2011, and the four anonymous reviewers for their comments on earlier drafts of this paper.

\section{REFERENCES}

Beneria, Lourdes 1982. “Accounting for Women's Work.” In Women and Development: The Sexual Division of Labor in Rural Societies, a study prepared for the International Labour Office within the framework of the World Employment Programme, edited by Lourdes Beneria, 119-47. New York: Praeger.

Carr, Marilyn, Martha Alter Chen, and Jane Tate. 2000. “Globalisation and Home-Based Workers." Feminist Economics 6(3): 123-42.

Carswell, Grace, and Geert de Neve. 2013. "T-Shirts and Tumblers: Caste, Dependency and Work under neoliberalisation in South India." Contributions to Indian Sociology 48(1): 103-31.

Cederlof, Gunnel. 1997. Bonds Lost: Subordination, Conflict and Mobilisation in Rural South India c. 1900-1970. New Delhi: Manohar.

Chari, Sharad. 2004. Fraternal Capital: Peasant Workers, Self-Made Men, and Globalization in Provincial India. Stanford, CA: Stanford University Press.

Charusheela, S. 2003. “Empowering Work? Bargaining Models Reconsidered.” In Toward a 
Feminist Philosophy of Economics, edited by Drucilla K. Barker and Edith Kuiper, 287303. London: Routledge.

da Corta, Lucia and Davuluri Venkateshwarlu. 1999. "Unfree Relations and the Feminisation of Agricultural Labour in Andhra Pradesh, 1970-95.” The Journal of Peasant Studies 26(23): 71-139.

De Neve, Geert and Grace Carswell. 2011. "From Field to Factory: Tracing Transformations in Bonded Labour in the Tiruppur Region, Tamil Nadu." Manchester Papers in Political Economy.http://www.socialsciences.manchester.ac.uk/PEI/publications/wp/documents/D eNeveandCarswell2011.pdf.

Desai, Sonalde and Veena Kulkarni. 2008. "Changing Educational Inequalities in India in the Context of Affirmative Action.” Demography 45(2): 245-70.

Deshpande, Ashwini. 2007. "Overlapping identities under Liberalization: Gender and Caste in India." Economic Development and Cultural Change, 55(4): 735-60.

Djurfeldt, Göran, Venkatesh B. Athreya, N. Jayakumar, Staffan Lindberg, A. Rajagopal, and R. Vidyasagar. 2008. "Agrarian Change and Social Mobility in Tamil Nadu." Economic and Political Weekly 43(45): 50-61.

Dreze, Jean and Amartya Sen. 1995. India: Economic Development and Social Opportunity. Oxford: Oxford University Press.

Dyson, Tim and Mick Moore. 1983. “On Kinship Structure, Female Autonomy, and Demographic Behaviour in India." Population and Development Review 9(1): 35-60.

Edholm, Felicity, Olivia Harris, and Kate Young. 1978. "Conceptualising Women.” Critique of Anthropology 3(9-10): 101-30. http://coa.sagepub.com/content/3/9-10/101.full.pdf.

Garda, Laila, Mallika Alexander, Rajib Acharya, Savita Kanade, and Shireen J. Jejeebhoy. 2010. 
“Measuring Agency Among Unmarried Young Women and Men." Economic and Political Weekly 45(30): 56-64.

Geetha, V. and S.V. Rajadurai. 1998. Towards a Non-Brahmin Millennium: From Iyothee Thass to Periyar. Calcutta: Samya.

Gorringe, Hugo. 2005. Untouchable Citizens: Dalit Movements and Democratization in Tamil Nadu. New Delhi: Sage Publications.

Gough, Kathleen. 1981. Rural Society in Southeast India. Cambridge: Cambridge University Press.

Government of Tamil Nadu [GoTN]. 2009. Tamil Nadu-An Economic Appraisal, 2008-9. Chennai: Department of Evaluation and Applied Research. http://www.tn.gov.in/dear/archives/year2008_09/index.htm

Guerin, Isabelle, Santhosh Kumar, and Isabelle Agier. 2013. “Women's Empowerment: Power to Act or Power over Other Women? Lessons from Indian Microfinance." Oxford Development Studies 41(1): 76-94.

Harriss-White, Barbara and S. Janakarajan. 2004. Rural India Facing the 21st Century: Essays on Long Term Village Change and Recent Development Policy. London: Anthem Press.

Heyer, Judith. 2010. "The Marginalisation of Dalits in a Modernising Economy.” In The Comparative Political Economy of Development: Africa and South Asia, edited by Barbara Harriss-White and Judith Heyer, 225-47. London: Routledge. ftp://s208.math.msu.su/515000/a30e56661c3f20c2bdf7fb31fee2e6d8.

---. 2012. "Labour Standards and Social Policy: A South Indian Case Study." Global Labour Journal 3(1): 91-117.

---. 2014 (forthcoming). “Dalit Women Becoming 'Housewives': Lessons from the Tiruppur 
Region, 1981/2 to 2008/9.” In Mobility and Marginalisation: Dalits in

Neoliberal India, edited by Clarinda Still. New Delhi: Routledge: 208-35.

Jejeebhoy, Shireen J. 2000. “Women's Autonomy in Rural India: Its Dimensions, Determinants and the Influence of Context." In Female Empowerment and Demographic Processes, edited by Harriet B. Presser and Gita Sen, 204-238. Oxford: Clarendon Press.

Jeyaranjan, J., John Harriss, and K. Nagaraj. 2010. "Land, Labour and Caste Politics in Rural Tamil Nadu in the $20^{\text {th }}$ Century: Iruvelpattu (1916-2008)." Economic and Political Weekly 45(31): 47-61.

Kabeer, Naila. 1996. “Agency, Well-Being and Inequality.” IDS Bulletin 27(1): 11-21.

---. 1999. "Resources, Agency, Achievements: Reflections on the Measurement of Women's Empowerment." Development and Change 30(3): 435-64.

Kapadia, Karin. 1995. Siva And Her Sisters: Gender, Caste, and Class in Rural South India. Oxford: Westview Press.

Koggel, Christine M. 2003. “Globalization and Women's Paid Work: Expanding Freedom?” Feminist Economics 9(2-3): 163-83.

Liddle, Joanna and Rama Joshi. 1986. Daughters of Independence: Gender, Caste, and Class in India. Kali for Women: New Delhi.

Lundberg, Shelly and Robert A. Pollak. 1993. "Separate Spheres Bargaining and the Marriage Market." Journal of Political Economy 101(6): 988-1010.

Mazumdar, Indrani and Neetha N. 2011. "Gender Dimensions: Employment Trends in India, 199394 to 2009-10." Economic and Political Weekly 46(43): 118-26.

McElroy, Marjorie B. 1992. "The Policy Implications of Family Bargaining and Marriage 
Markets.” Mimeo. Durham: Duke University.

http://www.ifpri.org/sites/default/files/pubs/pubs/jhu/households/intrahhresch04.pdf.

Mencher, J.P. 1988. "Women's Contribution to Household Maintenance in South India." In A Home

Divided: Women and Income in the Third World, edited by Daisy Dwyer and Judith Bruce, 99-119. Stanford: Stanford University Press.

Mies, Maria. 1982. Lace Makers of Narsapur: Indian Housewives Produce for the World Market. London: Zed Press.

Molyneux, Maxine. 1979. "Beyond the Domestic Labour Debate.” New Left Review 1(116): 3-27.

National Sample Survey Office (NSSO). 2010. Employment and Unemployment Situation in India 2007-08 - NSS $64^{\text {th }}$ Round (July 2007-June 2008). National Sample Survey Office, Ministry of Statistics \& Programme Implementation, Government of India. http://mospi.nic.in/rept $\% 20 \% 20$ pubn/531 final.pdf.

Prabhu, K. Seeta. 2001. Economic Reform and Social Sector Development: A Study of Two Indian States. New Delhi: Sage Publications.

Racine, Jean Luc and Josiane Racine. 1997. Viramma: Life of an Untouchable. London: Verso. Rao, Nitya. 2008. "Good Women Do Not Inherit Land": Politics of Land and Gender in India., New Delhi: Social Science Press and Orient Blackswan.

---. 2012. "Narratives of Constraint and Freedom: Marital Choice Amongst Dalit Women in a Tamil Nadu Village." Paper presented at workshop on Dalit Women's Narratives and Voices: Cross-Disciplinary Perspectives. University of East Anglia, Norwich. May 3-4. Ravindran, T.K. Sundari and P. Balasubramanian. 2012. "Pro-Poor Maternity Benefit Schemes and Rural Women: Findings from Tamil Nadu." Economic and Political Weekly 47(25): 19-22. 
Sen, Amartya. 1990. “Gender and Cooperative Conflicts.” In Persistent Inequalities:

Women and World Development, edited by Irene Tinker, 123-49. New York: Oxford University Press.

\section{NOTES}

${ }^{1}$ See, for instance, Maxine Molyneux 1979; and Lourdes Beneria 1982.

${ }^{2}$ In the 64th Round of the National Sample Survey (NSSO), 2007-8, women's work participation declined from the 1993-4 benchmark of 33 to 29 percent in rural areas and 17 to 14 percent in urban areas. Men's work participation remained stable (NSSO 2010).

${ }^{3}$ The Constitution of India, through its First Schedule, recognizes 1108 castes (Scheduled Castes) across twenty-five states and 744 tribes (Scheduled Tribes) across twenty-two states as historically deprived and marginalized groups. A three-pronged strategy including protective arrangements, affirmative action/reservations, and development policies were put in place to improve their situation.

${ }^{4}$ The price of rice has fluctuated from Rs 2.50/kg in 2006 to Re 1 in 2008 and made free in 2011 (Judith Heyer 2012).

${ }^{5}$ The Dr. Muthulakshmi Reddy Maternity Benefit scheme in Tamil Nadu provides support to poor women for a period of nine months, three during late pregnancy and childbirth and six following birth. The assistance was doubled from Rs 6000 to 12,000 per birth for the first two births in May 2011. However, T.K. Sundari Ravindran and P. Balasubramanian (2012) find in their five-district study that only 25 per cent of Dalit and landless women are able to access the financial benefits, partly due to the lengthy process of documentation. 
${ }^{6}$ Cederlof's (1997) historical analysis (1900-70) and Heyer's $(2010,2014)$ long-term study (1981-2008) proved invaluable for this purpose.

${ }^{7} 1 \mathrm{USD}=\mathrm{INR} 61.02$ as of March 13, 2014 